\title{
TANÍTÓJELÖLTEK KOMPETENCIAÉRZÉSÉNEK TANULMÁNYI ÉS TÁRSAS MEGHATÁROZÓI KOLTÓI LILLA
}

a Károli Gáspár Református Egyetem Bölcsészettudományi Karának adjunktusa koltoi.lilla@kre.hu

\begin{abstract}
A kompetenciák fejlödésének mértéke a hallgatói sikeresség egyik fontos mutatója. A hallgatói sikeresség modelljei szerint a sikerességet, a hallgatók fejlödését alapvetöen a tanulmányi és társas bevonódás segíti elö (Tinto, 1993; Weidman és mtsai, 2001). Ebböl kiindulva azt a kutatási célt tüztem ki, hogy a hallgatói kompetenciák, valamint akadémiai és társas meghatározóik közötti kapcsolatot elemezzem. A kutatásban a szubjektív kompetenciaérzés konstruktumával dolgoztam egyrészt Bandura (1993) kutatásaira, másrészt Ryan és Deci (2000) öndeterminációs elméletére alapozva. A kutatásban a Kecskeméti Főiskola Tanitóképzö Föiskolai Karának nappali tagozatos tanitó szakos hallgatói vettek részt $(n=199)$. Az eredmények szerint a tanulmányi tényezök nagyobb mértékben határozzák meg a kompetenciák észlelését, mint a társas tényezők. Az útvonalelemzés szerint a tanulmányi és társas meghatározók az általános kompetenciákon keresztül hatnak a pedagógiai kompetenciákra.
\end{abstract}

\section{Bevezetés}

A felsőoktatási kutatásokban egyre gyakrabban találkozunk a hallgatói kompetenciák leírásával, mérésével, a felsőoktatási intézmények vezetői egyre inkább támaszkodnak a kompetenciamérések eredményeire (Kiss, 2010b). A különbözö felsőoktatási képzések követelményét is egyre gyakrabban a szükséges kompetenciák leírásával adják meg. A hallgatói kompetenciamérés előnye, hogy egyrészt visszajelzést ad a felsőoktatási intézményeknek az oktatói munka eredményességéről, a hallgatók képességeiröl. Az általános és specifikus kompetenciák vizsgálata lehetővé teszi, hogy a hallgatók lehetséges teljesítményével kapcsolatosan elvárásokat fogalmazzunk meg, megvizsgáljuk, hogy a tanulás során használt és fejlesztett képességeik mennyire segítik elő a tanulmányi sikerességüket, a választott szakmára való felkészülésüket. Másrészt a kompetenciamérések eredményei alapján a hallgatók is tájékozódhatnak azokról a képességeikröl, amelyek szükségesek az általuk választott pályához. Ha bemeneti mérésként végezzük, képet kapunk a tanulmányaikat megkezdő hallgatók képességeiről, és az intézmény elő tudja készíteni a hallgatók fejlesztését a szükséges területeken. Ha kimeneti mérésként végezzük a kompetenciamérést, akkor a képzés eredményességét, a képzés hozzáadott értékét láthatjuk az eredményekben. A munkaadók oldaláról tekintve ugyancsak hasznos az elvárt hallgatói kompetenciák megfogalmazása, hiszen így segítik elő a friss diplomások zökkenőmentesebb 
beilleszkedését a munka világába (Kiss, 2010a). A CHEERS felmérés szerint a szakmai sikeresség mutatói között nagy szerepet játszanak a diplomaszerzésig elsajátított kompetenciák, megkönnyítik a diplomaszerzés és munkába állás átmenetét (Schomburg, 2010).

\section{A kompetenciáról}

A kompetenciának nincs egységes értelmezése, a fogalom meghatározásának nehézsége mellett szintén problémát jelent az operacionalizálás is, milyen eszközzel, a viselkedés melyik szintjét kell vizsgálni (Elliot - Dweck, 2005). A kompetencia értelmezését nehezíti az is, hogy több tudományterületen többféleképpen használják. A viselkedés sok szintjén használják a fogalmát: az egészen konkrét cselekvésektől (például: a dugót betenni a lyukba), a speciális eredményektől (például: egy teszten elért eredmény) a képességek jól beazonosítható mintázatán át (például: zongorázás), az átfogó jellemzőkig (például: intelligencia) és összetett jelenségekig (például: élet) (Elliot - Dweck, 2005).

A kompetenciát alapvető pszichológiai szükségletként megközelítő újabb elméletek (például: Skinner, 1995; Elliot és mtsai, 2002) kiemelik, hogy a kompetencia a hétköznapi élet minden területén hat, befolyásolja a kogníciót és a viselkedést kultúrától és életkortól függetlenül. Ilyen értelemben a kompetencia alapvető eleme a személyiség- és szubjektív jóllét elméleteknek (Elliot - Dweck, 2005). A kompetencia-megközelítések másik nagy csoportját azok a meghatározások és modellek alkotják (például: Weinert, 2001; Sternberg, 2005; Banta, 2001), amelyek a hangsúlyt a teljesítményhez szükséges képességekre helyezik. A kompetenciát olyan képességek összességének tartják, amelyek lehetővé teszik a magas szintü teljesítményt egy adott területen.

Bár a kompetencia eredendően pszichológiai konstruktum, mára multidiszciplináris fogalommá vált. Különböző tudományterületeken foglalkoznak vele, de elsősorban a pedagógiai kutatásokban jelent meg markánsan, ahol leginkább a képességalapú megközelítés a jellemző. A felsőoktatási kompetenciamérések egyik fontos célja a képzés - munkaerőpiac közötti átmenet megkönnyítése, ezért ezen a területen szintén a képességalapú megközelítés lett a domináns, erre jó példa az alábbiakban bemutatott Tuning projekt.

\section{A kompetenciák osztályozása}

Ahogy minden osztályozás, a kompetenciák osztályba sorolása is mesterséges, leegyszerüsítő, problematikus (Allen és mtsai, 2005). A legalapvetőbb felosztás Becker nevéhez köthetö. Munkahelyi kontextusban gondolkodva megkülönböztette az általános kompetenciákat, amelyek bármely szervezetben bármely pozícióban használhatók, a speciális kompetenciáktól, amelyek lehetnek cégspecifikusak vagy terület-, illetve feladatspecifikusak (Elliot és mtsai, 2005). Az általános és specifikus 
kompetenciák nagyban összefüggnek, de jelentőségüket eltérően értékelik a kutatók. Vannak kutatások, melyek az általános kompetenciák fontosságát hangsúlyozzák (Klein és mtsai, 2011), míg Weinert (2001) szerint a kognitív tudományok azt bizonyítják, hogy a kontextusfüggő, specifikus kompetenciák fontos szerepet játszanak a nehéz feladatok megoldásában, és az általános kompetenciák nem pótolják a speciális kompetenciák hiányát. Az általános kompetenciákat lehet specifikus kontextusban mérni (például: problémamegoldás), és a specifikus kompetenciák magukba foglalják, illetve feltételezik az általános kompetenciákat (Allen és mtsai, 2005).

\section{Kompetenciaosztályozási rendszerek}

Az Európai Unióban látunk törekvéseket egy egységes, közös kompetencialeltár, kompetenciakatalógus kialakítására a nemzetközi programok, fejlesztések összehangolása, a hatékony felsőoktatási képzés érdekében. A közös kompetenciakatalógus, például az ESCO, a Tuning projekt vagy az OECD kompetencialistája, a DeSeCo kompetenciarendszere akár alapot is teremthet a képzési programok egységes leírására, a kompatibilitás megalapozásához (Kiss Répáczki, 2012).

\section{A Tuning projekt modellje ${ }^{1}$}

A Tuning projekt előzménye a Deusto Egyetem kezdeményezésére induló átfogó kutatás volt 2000-ben. Ez az egyetemi kezdeményezés találkozott más európai egyetemek kezdeményezésével a felsőoktatás megújítására, így a Deusto és Gröningen Egyetem vezetésével útjára indult a Tuning projekt. Ma már több mint 200 európai egyetem csatlakozott a programhoz, és Latin-Amerikában, valamint Ázsiában is elindították a projektet. A kutatás fő célja a munkaadók pályakezdőkkel szembeni elvárásainak feltérképezése volt, illetve azoknak a kompetenciáknak a beazonosítása, amelyek megkönnyítik a felsőoktatás - munkába állás átmenetet.

A kompetenciákon alapuló tanulási megközelítés a tanulási folyamatot is átalakítja. A folyamat a tanuló autonómiájára és felelősségérzetére fókuszál (Tuning Competence Based Learning). A Tuning projekt modellje hangsúlyozza, hogy a sikeres hallgatói pályafutás nem csak az intellektuális teljesítőképességen múlik, hanem a hallgatói attitüdökön, motiváción, tanulási szokásokon, összességében a hallgatók tanulás iránti elkötelezettségére is nagy szükség van. A modell alapja a hallgató személyiségfejlődése, a hallgatók felelősségérzetének és elköteleződésének fokozatos növekedése a felsőfokú tanulmányaik alatt. A tanulás elősegíti a személyiségfejlődést és a személyes autonómiát. A modell szerint a felsőfokú végzettségüeket a gondolkodásmódjuk különbözteti meg azoktól, akik nem

${ }^{1}$ www.unideusto.org/tuningeu/ Letöltés ideje: 2017. szeptember 12. 
rendelkeznek diplomával, ezért az egyetemek egyik legfontosabb feladata a logikai - érvelő, jól strukturált - gondolkodás kialakítása. Ahhoz, hogy a társadalomban és a munkahelyen megtalálják a hallgatók majd a helyüket, szükséges instrumentális, interperszonális és rendszerszintű kompetenciákra szert tenniük, így az egyetemeknek is e kompetenciák fejlesztésére kell koncentrálni. Ezt igazolták a Tuning projekt kutatási eredményei is, amelyek azt mutatják, hogy a generikus (ún. átvihető) kompetenciák iránti munkaadói elvárások nagyobbak, mint a szakmaspecifikusak iránti elvárások (González - Wagenaar, 2008; Sánchez - Ruiz, 2008; Derényi, 2010).

A projekt kompetenciaosztályozása is az általános, vagyis generikus és specifikus alapfelosztáson alapul (1. táblázat). A generikus kompetenciákat három csoportra osztják: instrumentális, interperszonális és rendszerszintű kompetenciák, amelyeket még további alcsoportokra osztanak (González - Wagenaar, 2008; Sánchez - Ruiz, 2008).

2. táblázat: A generikus kompetenciák felosztása a Tuning projekt szerint (Forrás: saját táblázat a Tuning General Borchure (Sánchez - Ruiz, 2008) alapján

\begin{tabular}{|c|c|c|}
\hline \multirow{4}{*}{ 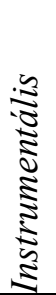 } & kognitív & $\begin{array}{l}\text { analitikus, szisztematikus, analógiás stb. gondolkodás, } \\
\text { kritikai képességek }\end{array}$ \\
\hline & módszertani & időgazdálkodás, problémamegoldás, tervezés \\
\hline & technológiai & $\begin{array}{l}\text { IKT eszközök használata a munkában, adatbázisok } \\
\text { kezelése }\end{array}$ \\
\hline & nyelvi & szóbeli és írásbeli kommunikáció, idegen nyelv ismerete \\
\hline \multirow{2}{*}{ 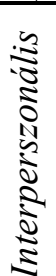 } & egyéni & $\begin{array}{l}\text { önmotiválás, alkalmazkodás a környezethez, etikai érzék, } \\
\text { interkulturalitás }\end{array}$ \\
\hline & társas & $\begin{array}{l}\text { csapatmunka, konfliktusmegoldás, } \quad \text { személyközi } \\
\text { kommunikáció }\end{array}$ \\
\hline \multirow{3}{*}{ 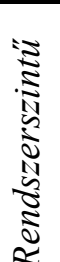 } & szervezeti & projektmenedzsment, minőségorientáltság \\
\hline & vállalkozói & kreativitás, vállalkozói szellem, innováció \\
\hline & vezetői & teljesítményorientáltság, vezetés \\
\hline
\end{tabular}

A generikus kompetenciák legfőbb jellemzői a multifunkcionalitás, transzferálhatóság, magasabb szintü mentális komplexitásra utalás, multidimenzionalitás. Az általános kompetenciák segítik a megküzdést a komplexitással (González - Wagenaar, 2008; Sánchez - Ruiz, 2008). 
Az általános kompetenciák leírása és osztályozása mellett kilenc tudományterület speciális kompetenciáit dolgozták ki: közgazdaságtan, kémia, matematika, ápolástan, fizika, Európai Uniós tanulmányok, pedagógia, történelem, földrajz.

\section{Hallgatói kompetenciaérzés}

A sikeres hallgatói életút alakulásában meghatározó szerepe van a hallgatók vélekedéseinek a saját képességeiről, a hallgatók önreflexióinak. A szakmához való viszonyulást, a szakmai sikerességet nagyban befolyásolják a képességekről alkotott énpercepciók. A kutatásban a tényleges kompetenciák helyett az észlelt kompetenciákat vizsgálom. Egyrészt abból a bandurai megállapításból indultam ki, hogy az egyén önmagáról alkotott percepciói jobb bejóslói a viselkedésének, mint a tényleges képességei (Bandura, 1993), mert az énpercepció aktív alakítója a teljesítménynek (Bong - Clarck, 1999). Másrészt egy korábbi, a munkatársaimmal végzett közös kutatásunkban arra találtunk bizonyítékot, hogy gyakran tévesek a hallgatók kompetenciákról alkotott percepciói. A kutatás nemcsak arra világított rá, hogy a bejövő hallgatók kompetenciái egyes területeken fejlesztésre szorulnak, hanem az is kiderült, hogy a hallgatók tényleges kompetenciái és önreflexiói nincsenek összhangban, a hallgatók gyakran alulértékelik a képességeiket, és ez kedvezőtlenül befolyásolja az akadémiai teljesítményüket (Hercz és mtsai, 2013). Erre alapozva lényegesnek gondolom a tényleges kompetenciák mellett a hallgatói percepciók vizsgálatát.

A kompetenciaérzés kifejezésben kihangsúlyozódik, hogy az észlelés kognitív aspektusa mellett ugyanolyan fontos a percepció affektív komponense is, amely szintén kihat a hallgatók eredményességére. Ez összhangban van azzal, amit Ryan és Deci (2002) öndeterminációs elméletük kapcsán kiemelt, azaz a kompetencia érzése fontosabb, meghatározóbb az egyén fejlődése szempontjából, mint annak tudása, hogy milyen képességeknek van birtokában.

\section{Hallgatói sikeresség}

A sikeresség külső mutatójaként tartják számon a diplomaszerzéstől az elhelyezkedésig számított idő hosszát, a munkahelyi beválást, de ide sorolható a piacképes tudás és a munkához szükséges kompetenciák színvonala (Kiss, 2010a; Pusztai, 2011). Ha a felsőoktatási intézmények müködését vesszük alapul, a sikeres hallgató az, aki benn tud maradni a rendszerben, a követelményeket időben tudja teljesíteni, és a belépéskori tudás- és képességszintjét meghaladja a kilépéskori, vagyis személyes fejlődés tapasztalható nála (Banta - Pike, 2007; Pusztai, 2011). A hallgató sikeressége az eredményességét is magában foglalja, így a hallgatói sikeresség kifejezhető a tanulmányi teljesítmény olyan objektív mutatóival, mint az osztályzat, tanulmányi átlag, a tanulmányok melletti kitartás (Astin, 1993; 
Pascarella - Terezini, 2005; Pike - Kuh, 2005b). Mások a képességek és kompetenciák fejlődésének mutatóival ragadják meg a fogalmat (Pike - Kuh, 2005a; Carini és mtsai, 2006). Ha a különbözö megközelítéseket ötvözzük, akkor azt mondhatjuk, hogy a hallgató akkor sikeres, ha jó színvonalú, piacképes szaktudással, megfelelő szintű szakmai és személyes kompetenciákkal lép ki a felsőoktatásból, illetve a megszerzett tudását és a képességeit kamatoztatni tudja a későbbi munkájában. A hallgató személyes és szakmai fejlódését nagyban elősegíti, ha képességeinek megfelelő kihívást jelent a felsőoktatási képzés, megélheti kompetenciáinak fejlődését, így a felsőoktatási intézmények ezt szem előtt tartva alapozhatják meg hallgatóik pszichológiai jóllétét, ami viszont csökkentheti a lemorzsolódás esélyét.

Több faktor is beazonosítható a hallgatói sikeresség hátterében. A bevonódási és hallgatói szocializációs modellekben fontos elemként jelenik meg a hallgatók tanulmányi és társas integrációja (például: Tinto, 1993), Weidman, 2001). A társas és tanulmányi integráció egymástól nem függetlenek, a csoporthoz tartozás igénye és képessége részben attól is függ, hogy képes-e a hallgató teljesíteni az adott tanulmányi szintet. Ehhez kellenek megfelelö, kognitív képességek, valamint idő és energia. Az intézményi tapasztalatok közvetlenül hatnak a kitartásra, és közvetetten hatnak a tanulmányi és társas integráción keresztül. Az a hallgató, aki bennmarad a képzésben és befejezi a tanulmányait, sikeresen vesz részt a hallgatói közösségben is. Aki tanórán kívüli tevékenységekben is részt vesz, aki kötődik a társakhoz és az oktatókhoz, valószínűleg sikeresebb lesz a tanulmányi teljesítményében is (Tinto, 1993).

A tanulmányi és társas integráció mellett az aktív tanulásnak is meghatározó szerepe van a sikerességben. Chickering (1974) a tanulmányi és társas tevékenységekben való aktív részvételt a hatékony tanulás feltételeként, a különböző élmények egy értelmes egésszé való integrálásaként határozta meg. Tinto (1993) integrációs modelljében a hallgatók aktív résztvevői a bevonódási folyamatnak. Az aktív tanulmányi részvételnek fontos szerepe van a hallgatók integrációjában, különös tekintettel az osztálytermi, kurzusokon folytatott munkára, föleg a különböző feladatok megoldása közben a társakkal folytatott interakcióknak tulajdonít nagy jelentőséget. A kooperatív tanulás, a tanuló közösségek fokozzák a hallgatók bevonódását, ezáltal nagyobb erőfeszítést tesznek a hallgatók, így hatékonyabbá és eredményesebbé válik a tanulás is. Braxton és mtsai (2000) szintén abból a tintoi megállapításból indultak ki, hogy a társas integráció az osztályteremben történik, mert a tanterem jelenti a kaput a társas és akadémiai közösség felé. Kutatási eredményeik szintén azt mutatják, hogy az aktív tanulási formák alkalmazása a kurzusokon (például: órai viták, kérdések, megbeszélések, kooperatív tanulás, szerepjáték) pozitívan hat a hallgatók bevonódására, az aktív tanulás az akadémiai integráció elözményének tekinthető. Következésképpen pozitívan befolyásolja az intézmény iránti elköteleződést és a képzésben maradás melletti döntést, illetve alakítja a hallgatók bevonódás mértékéről alkotott 
percepcióit. Az aktív tanulás és más osztálytermi tanítási gyakorlat az integrációra gyakorolt hatás forrását jelenti, és nem magát az integrációt (Braxton és mtsai, 2000).

Azoknak a hallgatóknak, akik rendszeresen aktív tanulási formákkal tanulnak, az önpercepciói is változnak: a tudásuk gyarapodása és az óra anyagának jobb megértése miatt az órai munkájukat hasznosnak, jutalmazónak látják. Ezek a percepciók arra motiválják a hallgatókat, hogy még több pszichológiai energiát fektessenek a csoporttagságuk megerősítésébe (Braxton és mtsai, 2000; Braxton és $m t s a i, 2008)$. Az aktív tanulási formák elősegítik a hallgatók közötti interakciók kialakulását a kurzusokon (Tinto, 2007), és ezek a kurzusokon létrejött interakciók vezetnek a kurzusokon kívüli társas kapcsolatok, barátságok kialakulásához, a társas támogatáshoz (Braxton és mtsai, 2008).

\section{A kutatás célja, módszerei}

A vizsgálat fö célja az észlelt hallgatói kompetenciák társas és tanulmányi meghatározóinak beazonosítása a tintoi elméletből kiindulva, azaz annak az elemzése, hogy a bevonódás mely tényezői a legfontosabb változók. Azt feltételeztem, hogy a tanulmányi és társas tényezők egyaránt meghatározzák az általános és specifikus (a vizsgálatban pedagógiai) kompetenciák észlelését.

A tanulmányi háttér meghatározó tényezői közül egyrészt a tanulmányi átlagot és a szerzett krediteket használtam, amelyekből egy objektív tanulmányi mutatót, az átlagos kreditmutatót képeztem ${ }^{2}$. Emellett szubjektív mutatókat is alkalmaztam, a hallgatók észlelt föiskolai énhatékonyságát és aktív tanulásról alkotott percepcióit mértem. Az előbbit az Owen-féle Főiskolai tanulmányi énhatékonyság skálával, míg az utóbbit az NSSE Aktív - kollaboratív tanulás alskálájával mértem.

A társas háttértényezők vizsgálatára objektív változóként a hallgatók föiskolai kurzusokon kívüli elfoglaltságainak, különböző föiskolai programokba való bevonódásának változóját használtam. A kérdőívben azokat föiskolai tevékenységet adtam meg, amelyek a karon elérhetők, különböző tudományos és művészeti mühelyhez kapcsolódnak. Szubjektív változóként a föiskolai társas kapcsolatok értékelését használtam, amelyet az NSSE Támogató föiskolai környezet alskálájával mértem. Ezek mellett a vizsgálatba bevontam a hallgatók értéktelítettségét is, mivel a hallgatói sikerességben a szükséges normák, értékrend elsajátítása is fontos tényező. Váriné (1987) meghatározása szerint „az értékek olyan társadalom-, illetve kultúrspecifikus eszmei objektivációk", amelyekben az ember és a társadalom közötti kapocs megragadható, az egyén értékelő viszonya világhoz és önmagához kifejezhető. A Schwartz-féle értékskálát használtam a vizsgálatban.

Az általános és pedagógiai kompetenciákat a Tuning project skáláival mértem (Generic Competence Scale, illetve Education Scale). A pedagógiai kompetencia

${ }^{2}$ Megszerzett kreditek és a félévek számának hányadosát a tanulmányi átlaggal azonos skálájúvá alakítottam, majd a tanulmányi átlag és az így kapott kreditmutató átlagát vettem. 
percepciójának mérésére alkalmaztam egy másik méröeszközt is. A Kecskeméti Főiskola Tanítóképző Főiskolai Kar tanító szakának képzési kimeneti követelményei kompetenciákban vannak megfogalmazva, ezért skálává átalakítva mérőeszközként használtam.

\section{Minta}

A kutatást a Kecskeméti Főiskola Tanítóképző Karán végeztem. A vizsgálatban nappali tagozatos tanító szakos hallgatók vettek részt. A kitöltési hajlandóság nagy volt, az aktív féléves hallgatók több mint 95\%-a töltötte ki a teszteket ( $\mathrm{n}=199)$. A kutatás mintája viszonylag homogén a demográfiai háttérváltozók szerint: a hallgatók nagy része vidéki kisvárosból vagy falvakból származó nő, aki első helyen jelölte meg a Kecskeméti Főiskola Tanítóképző Karát.

\section{Eredmények}

A tanulmányi meghatározók átlag és szórás értékei azt mutatják, hogy a minta viszonylag homogén. A tanulmányi énhatékonyság és aktív tanulásértékei arra utalnak, hogy a tanítójelöltek inkább pozitívan értékelik magukat az adott dimenziókban (2. táblázat).

2. táblázat: Az átlagos kreditmutató átlaga és szórása

\begin{tabular}{|l|l|l|}
\hline Tanulmányi változók & $M$ & $S D$ \\
\hline Átlagos kreditmutató (5 fokú Likert skálán) & 3,75 & 0,39 \\
\hline Főisk. tanulm. énhatékonyság (5 fokú Likert skálán) & 3,75 & 0,44 \\
\hline Aktív tanulás (4 fokú Likert skálán) & 2,31 & 0,44 \\
\hline
\end{tabular}

Az aktív tanulás itemeinek faktorelemzésével három faktort kaptam: az első faktor az oktatókkal való kapcsolatra vonatkozó állításokat, a második a hallgatótársakkal való közös tevékenységet leíró állításokat és a harmadik az otthoni készüléssel járó feladatokra vonatkozó itemeket tömöríti.

A társas változók közül a Kurzusokon kívüli föiskolai elfoglaltságok esetében 10 kategória szerepelt a kérdőívben (3. táblázat). A gyakorisági táblázat azt mutatja, hogy a hallgatók kevés programban vesznek részt (átlag 1,35; szórás:1), még a sport és a föiskolai bulik is csak kevesebb, mint a hallgatók felét vonzzák. Ennek a magyarázata a tanítójelöltek túlterheltsége (a magas heti óraszám mellett gyakorlat is van) és az, hogy a hallgatók nagy része ingázik, ezért a hagyományosan a későbbi időpontokban kezdődő elfoglaltságokra nem tudnak elmenni. 
3. táblázat: Az átlagos kreditmutató átlaga és szórása

\begin{tabular}{|c|c|c|c|c|c|c|c|c|c|}
\hline Sport & Zene & Dráma & HÖK & Rendez. & Tutor & TDK & Szakkoll. & Buli & Egyéb \\
\hline 82 & 31 & 24 & 3 & 21 & 9 & 10 & 5 & 69 & 15 \\
\hline
\end{tabular}

A főiskolai társas kapcsolatok esetében a tanítójelölteknek értékelni kellett, milyen viszonyban vannak a föiskolai csoporttársaikkal, oktatóikkal és az adminisztratív dolgozókkal. Hétfokú skálán ítélték meg a hallgatók, mennyire barátságos, támogató a kapcsolat. Az átlagok viszonylag magas értékei arra utalnak, hogy a föiskola társas közegét pozitívnak érzékelik a hallgatók (4. táblázat).

4. táblázat: A hallgatók intézményi kapcsolati elégedettségének átlagai és szórásai

\begin{tabular}{|l|l|l|l|l|l|}
\hline \multicolumn{2}{|c|}{ Kapcsolat a hallgatókkal } & \multicolumn{2}{|c|}{ Kapcsolat az oktatókkal } & \multicolumn{2}{l|}{ Kapcsolat a hivatalokkal } \\
\hline $\mathrm{M}$ & $\mathrm{SD}$ & $\mathrm{M}$ & $\mathrm{SD}$ & $\mathrm{M}$ & $\mathrm{SD}$ \\
\hline 5,93 & 1,04 & 5,14 & 1,20 & 4,24 & 1,29 \\
\hline
\end{tabular}

A Schwartz-értékskála itemeit hatfokú skálán ítélték meg a válaszadók, skála összpontszáma az értéktelítettséget mutatja meg. Az átlag és szórás értékei ( $\mathrm{M}=$ 4,38; $\mathrm{SD}=0,46$ ) viszonylag magas értéktelítettségre utalnak.

Az általános kompetenciák percepciója esetében a tanítójelöltek ötfokú skálán ítélték meg a kompetenciáikat. Az átlag és szórás $(\mathrm{M}=3,79 ; \mathrm{SD}=0,38)$ azt mutatja, hogy a hallgatók a közepesnél jobbnak ítélik meg a kompetenciáikat. A faktorelemzés eredménye azt mutatja, hogy a faktorok száma ugyan megegyezik a Tuning projekt általános kompetenciák faktorszámaival, viszont a faktorok tartalma némileg eltér az eredetitől, az itemek más struktúrában rendeződnek a három faktorba. Az első faktort az Alapkompetenciák faktorának neveztem el, amelyekre a felsőoktatásban tanuló hallgatóknak a sikeres hallgatói pályafutáshoz szükségük van. A második faktor a Társas faktor, amelybe belekerült a kreativitás is. A harmadik faktor az Értelmiségi lét kompetenciáit takarja, azaz olyan kompetenciákat, amelyek a felsőfokú végzettséggel rendelkezők szélesebb, társadalmi orientációjához kapcsolódnak. A legmagasabb értékeket az Társas kompetenciák dimenziójában találtam $(\mathrm{M}=3,98, \mathrm{SD}=0,54)$, ennél alacsonyabb értéket mutatott az Értelmiségi dimenzió $(\mathrm{M}=3,76, \mathrm{SD}=0,46)$ és az Alapkompetenciák percepciója $(\mathrm{M}=3,72, \mathrm{SD}=0,52)$.

A pedagógiai kompetencia percepcióját a Tuning projekt Education scale magyar változatával és a Kecskeméti Főiskola Tanítóképző Főiskolai Kar tanító szakának képzési kimeneti követelményeiben megfogalmazott kompetenciákból kialakított $K K K$ skála segítségével mértem, minkét esetben ötfokú Likert skálán ítélték meg az állításokat a hallgatók. Megnéztem a két pedagógiai kompetenciát mérö skála kapcsolatát, és erős korrelációt találtam $(r=0,776 ; \mathrm{p}<0,000)$, ezért egy 
közös mutatót képeztem. A minta átlaga arra utal, hogy a tanítójelöltek a közepesnél valamivel jobbnak ítélik meg pedagógiai kompetenciáikat (5. táblázat).

5. táblázat: A Tuning projekt Education Scale, a KKK skála és a közös mutató átlaga és szórása

\begin{tabular}{|l|l|l|l|l|l|}
\hline \multicolumn{2}{|c|}{ Tuning Edu. } & \multicolumn{3}{c|}{ KKK } & \multicolumn{2}{c|}{ Pedagógiai komp. } \\
\hline $\mathrm{M}$ & $\mathrm{SD}$ & $\mathrm{M}$ & $\mathrm{SD}$ & $\mathrm{M}$ & $\mathrm{SD}$ \\
\hline 3,86 & 0,44 & 3,84 & 0,46 & 3,88 & 0,41 \\
\hline
\end{tabular}

\section{A változók közötti összefüggések}

Az észlelt általános kompetenciák és az észlelt pedagógiai kompetencia között erős, szignifikáns korreláció van $(\mathrm{r}=0,737 ; \mathrm{p}<0,000)$. Az általános kompetencia faktorai szintén szignifikánsan korrelálnak a pedagógiai kompetenciával. $\mathrm{Az}$ Alapkompetenciák faktor mutatja a legerősebb kapcsolatot $(r=0,648 ; p<0,000)$ az észlelt pedagógiai kompetenciával, de erős a kapcsolat az Értelmiségi faktorral $(\mathrm{r}=$ $0,538 ; \mathrm{p}<0,000)$ is. A legkevésbé erős korreláció a pedagógiai kompetencia és a Társas faktor között van $(\mathrm{r}=0,463 ; \mathrm{p}<0,001)$.

6. táblázat: Az általános és pedagógiai kompetenciák korrelációi a tanulmányi és társas meghatározókkal

\begin{tabular}{|l|l|l|l|l|l|}
\hline & $\begin{array}{l}\text { Fóisk. tan. } \\
\text { énhatékonyság }\end{array}$ & $\begin{array}{l}\text { Aktív } \\
\text { tanulás }\end{array}$ & $\begin{array}{l}\text { Fóisk. társas } \\
\text { kapcs. }\end{array}$ & Értéktelitettség & $\begin{array}{l}\text { Kurzusokon } \\
\text { kív.elfogl. }\end{array}$ \\
\hline $\begin{array}{l}\text { Ált. } \\
\text { komp. }\end{array}$ & $0,63^{* * *}$ & $0,57^{* * *}$ & $0,46^{* *}$ & $0,35^{* *}$ & $0,25^{* *}$ \\
\hline $\begin{array}{l}\text { Ped. } \\
\text { komp. }\end{array}$ & $0,46^{* *}$ & $0,46^{* *}$ & $0,40^{* *}$ & $0,33^{* *}$ & $0,18^{*}$ \\
\hline
\end{tabular}

A tanulmányi meghatározók változói közül a föiskolai tanulmányi énhatékonyság mutatta a legerősebb szignifikáns kapcsolatot az észlelt általános és pedagógiai kompetenciákkal. Az aktív tanulás skálaátlaga szintén szignifikánsan korrelál a kompetenciákkal, de valamivel gyengébb a kapcsolat mind az általános kompetenciákkal, mind a pedagógiai kompetenciával (6. táblázat). Ha az észlelt kompetenciák és az aktív tanulás faktorainak a kapcsolatát vizsgáljuk, akkor is az látható, hogy erősebb a kapcsolat az általános kompetenciákkal, mint a pedagógiai kompetenciával. A legerősebb korreláció az Oktató faktor és az általános kompetenciák között van $(\mathrm{r}=0,449, \mathrm{p}<0,01)$, az észlelt pedagógiai kompetencia esetében gyengébb, de szignifikáns kapcsolatot látunk $\mathrm{r}=0,386, \mathrm{p}<0,01) . \mathrm{Az}$ általam képzett átlagos kreditmutató csak tendenciaszerü kapcsolatot mutatott a 
kompetenciákkal: általános kompetenciákkal $\mathrm{r}=0,196, \mathrm{p}<0,05$; pedagógiai kompetenciával $\mathrm{r}=0,166, \mathrm{p}<0,05$ erősségü az összefüggés. Azonban az általános kompetencia Értelmiségi faktorával gyenge, de szignifikáns a korreláció $(r=0,214$; $\mathrm{p}<0,01$ ).

A társas tényezők közül a kurzusokon kívüli elfoglaltságok csak az észlelt pedagógiai kompetenciával korreláltak, de ez a kapcsolat is gyenge. Az észlelt általános kompetenciákkal tendenciaszerü a kapcsolat (6. táblázat). A Schwartz értékskála átlagpontszáma szignifikánsan korrelál mind az általános kompetenciákkal, mind a pedagógiai kompetenciával (6. táblázat). A föiskolai kapcsolatok mutatója szignifikánsan korrelál az általános kompetenciákkal és a pedagógiai kompetenciával is (6. táblázat). Ha a föiskolai kapcsolatokat komponensei szerint vizsgáljuk, akkor az látható, hogy az oktatókkal való kapcsolat korrelál a legerősebben az általános és pedagógiai kompetenciák észlelésével $(\mathrm{r}=$ 0,455 , illetve $0,397, \mathrm{p}<0,01$ ), de a hallgatókkal való kapcsolat esetében is szignifikáns, közepes erősségü a korreláció $(\mathrm{r}=0,33$, illetve $0,298, \mathrm{p}<0,01)$. Ezek az eredmények a fontos szocializációs ágensek hatását tükrözik az énpercepciókra.

\section{Modell}

A korrelációs elemzések alapján modellbe szerveztem a változókat. Az eredményekből kiderült, hogy az észlelt kompetenciák feltételezett tanulmányi és társas meghatározói erősebben kapcsolódnak az általános kompetenciákhoz, mint a pedagógiai kompetenciához. Bár a változók oda-vissza hatnak egymásra, a modellben a feltételezett fő irányok szerepelnek. Így az általános kompetenciákra épül a pedagógiai kompetencia egyrészt a szakirodalmi megfontolások miatt, másrészt a tanulmányi, valamint társas meghatározók és a kompetenciák közötti korrelációk erőssége is afelé mutat, hogy a tanulmányi és társas tényezők az általános kompetenciák észlelésén keresztül hatnak. Ezért azt feltételeztem, hogy a tanulmányi és társas változók az általános kompetenciákon keresztül fejtik ki a hatásukat a pedagógiai kompetenciákra. A változók közötti kapcsolatot lineáris regresszióval és útvonalelemzéssel ellenőriztem, amelyhez az Amos 20 szoftvert használtam.

A korrelációs eredmények alapján a modellbe a föiskolai tanulmányi énhatékonyság, aktív tanulás, föiskolai kapcsolatok és az értéktelítettség (Schwartz skálaátlag) mutatóját vettem be. A modell jó $(F=54,95 ; p=0,000)$, magyarázó ereje nagy (adjusted $\mathrm{R}^{2}=0,523$ ). Az együtthatók béta értékeiből és szignifikanciáiból az látszik, hogy a társas tényezők hatása valamivel gyengébb, mint a tanulmányi tényezőké (7. táblázat). 
7. táblázat: Az általános kompetenciák társas és tanulmányi együtthatóinak értékei és szignifikanciái a lineáris regresszióban stepwise módszerrel

\begin{tabular}{|l|l|l|l|l|l|l|}
\hline \multirow{2}{*}{ Modell } & \multicolumn{2}{|c|}{$\begin{array}{c}\text { Nem standard. } \\
\text { koefficiensek }\end{array}$} & \multicolumn{1}{c|}{$\begin{array}{c}\text { Standard. } \\
\text { koefficiens }\end{array}$} & \multirow{2}{*}{$t$} & \multirow{2}{*}{ szignif. } \\
\cline { 3 - 5 } & B & Stand. hiba & Béta & & \\
\hline 1 & (konstans) & 1,74 & 0,18 & & 9,50 &, 000 \\
\hline & Föisk. énhat. & 0,54 & 0,05 & 0,62 & 11,21 &, 000 \\
\hline 2 & (konstans) & 1,61 & 0,17 & & 9,39 &, 000 \\
\hline & Föisk. énhat. &, 040 & 0,05 & 0,46 & 7,74 &, 000 \\
\hline & Aktív tanulás & 0,29 & 0,05 & 0,34 & 5,79 &, 000 \\
\hline 3 & (konstans) & 1,44 & 0,17 & & 8,29 &, 000 \\
\hline & Föisk. énhat. & 0,34 & 0,05 & 0,39 & 6,29 &, 000 \\
\hline & Aktív tanulás & 0,27 & 0,05 & 0,32 & 5,50 &, 000 \\
\hline & $\begin{array}{l}\text { Föisk. } \\
\text { kapcsolatok }\end{array}$ & 0,09 & 0,03 & 0,19 & 3,41 &, 001 \\
\hline 4 & (konstans) & 1,00 & 0,22 & & 4,50 &, 000 \\
\hline & Föisk. énhat. & 0,33 & 0,05 & 0,37 & 6,22 &, 000 \\
\hline & Aktív tanulás & 0,25 & 0,05 & 0,29 & 4,99 &, 000 \\
\hline & $\begin{array}{l}\text { Föisk. } \\
\text { kapcsolatok }\end{array}$ & 0,08 & 0,02 & 0,17 & 3,13 &, 002 \\
\hline & $\begin{array}{l}\text { Schwartz- } \\
\text { értékek }\end{array}$ & 0,13 & 0,04 & 0,16 & 3,09 &, 002 \\
\hline
\end{tabular}

A tanulmányi és társas tényezők együttes hatását az észlelt pedagógiai kompetenciára szintén megnéztem. A modell szignifikáns, de magyarázó ereje kisebb $\left(\mathrm{F}=26,61\right.$; adjusted $\left.\mathrm{R}^{2}=0,342\right)$. Az együtthatók béta értékei is alacsonyabbak, kivéve a Schwartz-értékeket (Föiskolai énhatékonyság $\beta=0,217$; Aktív tanulás $\beta=0,245$; Föiskolai kapcsolatok $\beta=0,203$; Schwartz $\beta=0,179$ ).

Az útvonalelemzés megerősítette a lineáris regresszió eredményét. A 1. ábrából látható, hogy az észlelt általános kompetenciák nagymértékben meghatározzák az észlelt pedagógiai kompetenciát. Az együtthatók azt mutatják, hogy a tanulmányi meghatározók erősebb hatással vannak az észlelt általános kompetenciákra, mint a pedagógiaira. A föiskolai társas kapcsolatok magyarázóereje kisebb a vártnál, ebben a modellben ez a változó van legkisebb hatással (1. ábra). A tanulmányi változók közötti kovariancia értékei arra utalnak, hogy a változók egymásra is hatással vannak. Ez az értéktelítettség esetében mérsékelt erősségü, míg a kurzusokon kívüli elfoglaltságok esetében gyenge. A modell illeszkedési mutatóinak az értékei jók (CMIN/DF: 1,86; CFI: 0,996; RMSEA: 0,021), a modell elfogadható. 


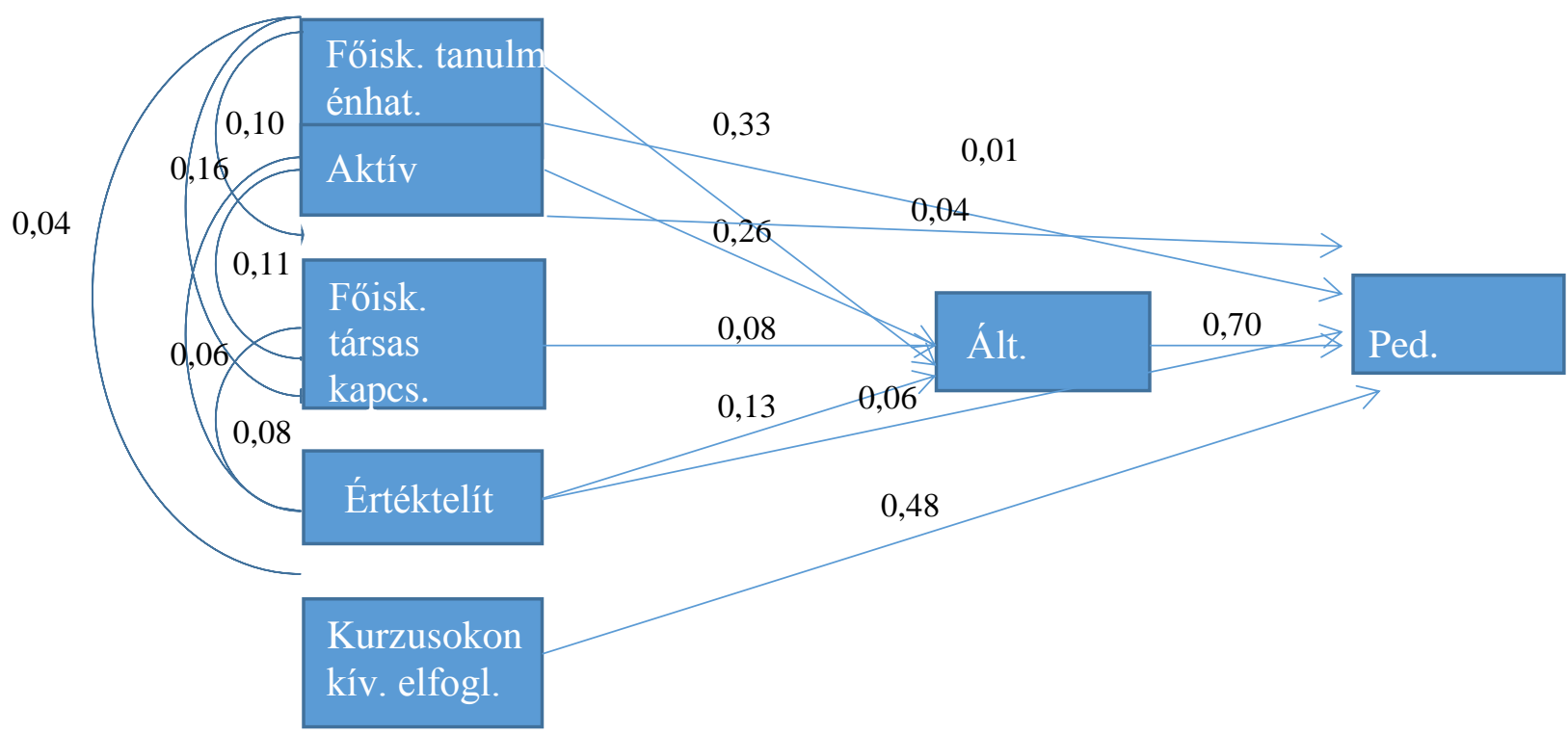

1. ábra: A modell útvonalelemzése

\section{Diszkusszió}

A tanítójelöltek percepciói a képességeikröl, a kompetenciáikról pozitív, a többség inkább elégedett a kompetenciái színvonalával, mint sem elégedetlen. Ezeknek a területeknek a vizsgálata azokat a képességeket célozza, amelyek a föiskolai sikeres pályafutáshoz nélkülözhetetlenek, így jól jelezheti a problémákat, illetve a fejlesztendő területeket. A korrelációs és útvonalelemzések alapján az mondható, hogy az észlelt kompetenciák szorosan összefüggnek, az általános kompetenciákra épül a pedagógiai.

A tanítójelöltek bevonódását vizsgáló kutatások eredményeihez hasonlóan (például: Tinto, 1993; Pascarella - Terezini, 2005) a jelen kutatási eredmények szerint is van kapcsolat a társas és tanulmányi változók között, a két tényezöcsoport egymással korrelálva, de egymástól függetlenül gyakorol hatást a kompetenciák percepciójára. A kutatási eredmények igazolták azt a feltevést, hogy a tanulmányi és társas bevonódás változói szignifikáns kapcsolatban állnak a kompetenciák észlelésével. Az eredmények szerint a meghatározók erősebb kapcsolatban vannak az általános kompetenciákkal, mint a pedagógiaival. Ez alól a kurzusokon kívüli főiskolai elfoglaltságok változója volt a kivétel, mert ez a változó a pedagógiai 
kompetenciával áll szignifikáns kapcsolatban, az általános kompetenciákkal nincs szignifikáns kapcsolata.

Összességében az mondható a tanulmányi és társas meghatározó tényezőkröl, hogy a föiskolai tanulmányi énhatékonyság, az aktív tanulás, a főiskolai társas kapcsolatok minősége és a tanítójelöltek értéktelítettsége az általános kompetenciákra hatnak jobban, a pedagógiai kompetenciára inkább indirekt hatással vannak. A kurzusokon kívüli föiskolai elfoglaltságok a pedagógiai kompetencia percepciójával állnak összefüggésben. A TDK és szakkollégiumi tevékenységben, tutor és mentor programban való részvétel valószínűleg a szakmai kompetenciák fejlődését segítik elő, de lehetséges, hogy a dráma- és zenei foglalkozásokon is célzottan a pedagógus pályára készülnek a hallgatók, így a szakmai kompetenciák fejlesztésére nagy hangsúlyt fektetnek azokban a tevékenységekben is. Az eredmények egyértelmüen azt mutatják, hogy a tanítójelöltek aktív részvétele a kurzusokon, a föiskola tanulmányi és hallgatói életében - tulajdonképpen a tanulmányi és társas bevonódásuk -, jótékonyan hat a kompetenciáikra, minél aktívabbak a tanítójelöltek, annál pozitívabb a kompetenciáik percepciója.

Az eredmények alapján az mondható, hogy mindenféleképpen megfontolandó a pedagógusképzésben helyet adni olyan kurzusnak, kurzuson kívüli tevékenységnek, amely lehetőséget ad a tanítójelölteknek arra, hogy egy leendő pedagógusokból álló szakmai közösség aktív és hatékony tagjai legyenek. Mivel a személyes szakmai kapcsolatok fontos tényezői a hallgatói sikerességnek és a szakmai szocializációnak, ezért a tanítóképzésben érdemes lenne hallgatói csoportokat kialakítani, és a csoportokhoz mentorhallgatókat, esetleg mentortanárokat rendelni. A kutatási eredmények ez utóbbi fontosságát is igazolják, hiszen a hallgató - oktató kapcsolat nagyban hat a tanítójelöltek kompetenciaérzésére, vagyis az oktatókkal kialakított személyes szakmai kapcsolat elősegíti a pedagógussá válás folyamatát.

\section{Összegzés}

A kutatással a tanítójelöltek percepcióinak összefüggéseit tártam fel, ami megfontolásra érdemes eredményeket hozott a hallgatói sikeresség további kutatásának szempontjából. A hallgatók támogatása érdekében a tárgyi, szakmai tudás fejlesztése mellett figyelmet kell fordítani a kompetenciáik fejlesztésére, hogy képessé tegye az intézmény a hallgatóit a hatékony múködésre, a problémákkal való megküzdésre. Ehhez viszont szükség van a tanítójelöltek önismeretének, reflexív tudatosságának erősítésére, énfogalmuk, énképük differenciáltabb percepciójának kialakítására.

A hallgatói percepciók vizsgálatának ötvözése a tanulmányi teljesítményük, tényleges kompetenciáik kutatásával pontosabb képet adhatna a hallgatói sikerességet meghatározó tényezőkröl. Egy szélesebb körü kutatás lehetővé tenné, 
hogy a hallgatók fejlesztésére, sikerességük elősegítésére komplex, a hallgatók jellemzőinek és igényeinek megfelelő programokat dolgozzanak ki az intézmények.

\section{Irodalom}

Allen, J. - Ramaekers, G. - Velden, van der R. (2005): Measuring Competencies. In: Weerts, D. J. - Vidal, J. (eds): Enhancing Alumni Research: European and American Perspectives, New Directions for Institutional Research, Number 126, Jossey-Bass, San Francisco, 49-59.

Astin, A. W. (1993): What matters in college? Four critical years revisited. Jossey-Bass, San Francisco.

Bandura, A. (1993): Perceived Self-Efficacy in Cognitive Development and Functioning. Educational Psychologist, 28 (2), 117-148.

Banta, T. W (2001): Assessing competences in higher education. In: Palomba, C. A. - Banta, T. W. (eds.): Assessing student competence in accredited disciplines: pioneering approaches to assessment in higher education. Stylus Publishing, Sterling, Virginia, Canada. Chapter $\quad$ I. $\quad$ http://www.google.hu/books?id=96y5eOv7AC\&printsec=frontcover\#v=onepage\&q\&f=true Letöltés ideje: 2017. január 15.

Banta, T.W. - Pike, G. R. (2007): Revisiting the blind alley of value added. Assessment Update, 19 1:1-15.

Bong, M. - Clark, R. E. (1999): Comparison between Self-Concept and Self-Efficacy in Academic Motivation Research. Educational Psychologist, 34 (3), 139-153.

Braxton, J. M. - Milem, J. F. - Sullivan, A. V. (2000): The influence of active learning on the college student departure process: Toward a revision of Tinto's theory. Journal of Higher Education, 71 (5), 569-590.

Braxton, J. M. - Jones, V. A. - Hirschy, A. S. - Hartely, H. V. (2008): The Role of Active Learning in College Student Persistence. New Directions for Teaching and Learning, No. $115.71-83$.

Carini, R. M. - Kuh, G. D. - Klein, S. P. (2006): Student Engagement and Student Learning: Testing the Linkages. Research in Higher Education, Vol 47, No.1. 1-32.

Chickering, A. (1974): Commuting versus residential students: Overcoming educational inequities of living off campus. San Francisco: Jossey-Bass

Derényi András (2010): A magyar felsőoktatási képesítési keretrendszer átfogó elemzése. Iskolakultúra, 5-6. sz. 3-10.

Elliot, A. J. - Dweck, C.S. (2005): Competence as the Core of Achievement Motivation. In: Elliot, A. J. - Dweck, C. S. (eds): Handbook of Competence and Motivation. The Guilford Press, New York

Elliot, A. J. - McGregor, H. A. - Thrash, T. M. (2002): The need for competence. In: Deci, E. L. - Ryan, R. M. (eds): Handbook of self-determination research. University of Rochester Press, Rochester NY

González, J. - Wagenaar, R. (eds. 2008): Tuning Brochure, Universities' Contribution to Bologna Process. Tuning Project 
Hercz Mária - Koltói Lilla - Pap-Szigeti Róbert (2013): Hallgatói kompetenciaértékelés és modellkutatás. Felsőoktatási Mühely, 1. sz. 83-99.

Kiss István - Répáczki Rita (2012): Új készségek és munkahelyek: a kompetencia megközelitésére épülö szolgáltatások szerepe a foglalkoztathatóság javitásában. Munkaerőpiacorientált felsőoktatás, TEMPUS.

Kiss Paszkál (2010a): Felsőfokú kompetenciákról nemzetközi kitekintésben. In: Kiss Paszkál (szerk.): Diplomás Pályakövetés III, Kompetenciamérés a felsőoktatásban, Educatio, 15-24.

Kiss Paszkál (2010b): Diplomás kompetenciaigény és munkával való elégedettség. In: Kiss Paszkál (szerk.): Diplomás Pályakövetés IV, Tematikus tanulmányok, Educatio, 105122.

Klein, S. - Benjamin, R. - Shavelson, R. - Bolus, R. (2011): Felsőfokú Tanulási Eredmények Értékelése (CLA): Tények és hiedelmek. Felsőoktatási Mühely, 4. sz. 17-32.

Koltói Lilla - Kiss Paszkál (2011): Értelmiségi utánpótlás - politikai jártasság és végzettség összefüggése a fiatal felnőttek között. Felsőoktatási Mühely, 4. sz. 81-94.

Pascarella, E. T. - Terenzini, P. T. (2005): How college affects students: Vol. 2. A third decade of research. Jossey-Bass, San Francisco.

Pike, G. R. - Kuh, G. D. (2005a): A Typology of Student Engagement for American Colleges and Universities. Research in Higher Education, Vol. 46, No. 2, 185-209.

Pike, G. R. - Kuh, G. D. (2005b): First- and Second-Generation College Students: A Comparison of Their Engagement and Intellectual Development. Journal of Higher Education. Vol.76, No.3, 276-300.

Pusztai Gabriella (2011): A láthatatlan kéztől a baráti kezekig. Hallgatói értelmezői közösségek a felsőoktatásban. Új Mandátum Könyvkiadó.

Ryan, R. M. - Deci, E. L. (2002): An overview of self-determination theory. In: Deci, E. L. - Ryan, R. M. (eds.): Handbook of self-determination research. 3-33. NY: University of Rochester Press, Rochester.

Sánchez, A. V. - Ruiz, M. P. (2008): Competence-based learning. http://www.unideusto.org/tuningeu/images/stories/Publications/Book_Competence_ Based_Learning.pdf_Letöltés ideje: 2017. január 15.

Skinner, E. A. (1995): Perceived control, motivation, and coping. CA: Sage Publications, Newbury Park.

Sternberg, R. J. (2005): Intelligence, Competence, and Expertise. In: Elliot, A. J. - Dweck, C. S. (eds): Handbook of Competence and Motivation. The Guilford Press, New York. 15-30.

Tinto, V. (2007). Research and practice of student retention: What next? Journal of College Student Retention: Research, Theory \& Practice, 8 (1), 1-19.

Tinto, V. (1993): Leaving college: Rethinking the causes and cures of student attrition (2nd ed.). IL: University of Chicago Press, Chicago.

Schomburg, H. (2010): Felsőfokú diplomások szakmai sikeressége. In: Kiss Paszkál (szerk.): Diplomás Pályakövetés III, Kompetenciamérés a felsőoktatásban, Educatio, 25-47.

Weidman, J.C. - Twale, D. - Stein, E. L. (2001): Socialization of Graduate and Professional Students in Higher Education: A Perilous Passage? Jossey-Bass, San Francisco.

Weinert, F. E. (2001): Concept of Competence: A Conceptual Clarification. In: Rychen, D. S. - Salganik, L. H. (eds.): Defining and Selecting Key Competencies. Wash.: Hofgrefe\& Huber, Seattle. 45-65. 